\title{
TO COMPARE THE EFFICACY OF INTRAVENOUS MIDAZOLAM VERSUS CLONIDINE AS PREMEDICANTS ON BISPECTRAL INDEX-GUIDED PROPOFOL INDUCTION OF ANAESTHESIA IN GENERAL SURGERY
}

\author{
Tarun Lall1, Digvijay Singh², Vishnu Dutta ${ }^{3}$,Vinod Meena ${ }^{4}$
}

1 Professor, Department of Anaesthesia, Sawai Man Singh Medical College and Associated Group of Hospital, Jaipur, Rajasthan, India. ${ }^{2}$ Resident, Department of Anaesthesia, Sawai Man Singh Medical College and Associated Group of Hospital, Jaipur, Rajasthan, India. ${ }^{3}$ Resident, Department of Anaesthesia, Sawai Man Singh Medical College and Associated Group of Hospital, Jaipur, Rajasthan, India. ${ }_{4}^{4}$ Resident, Department of Anaesthesia, Sawai Man Singh Medical College and Associated Group of Hospital, Jaipur, Rajasthan, India. ABSTRACT

\section{BACKGROUND}

Laryngoscopy and endotracheal intubation are potent stimuli that can induce increased sympathetic activity leading to tachycardia, hypertension and dysrhythmias. Various drugs and methods have been tried to obtund this response. Studies are still continued to obtain ideal drugs. We compared the efficacy of midazolam and clonidine to attenuate the pressor response during laryngoscopy and intubation.

\section{MATERIALS AND METHODS}

Total 135 patients of ASA grade I and II, scheduled for elective surgery under general anaesthesia were randomised into three groups. Group A received intravenous midazolam $50 \mathrm{mcg} / \mathrm{kg}$, diluted in normal saline 20 mins prior to surgery. Group B received intravenous clonidine $1.5 \mathrm{mcg}$ diluted in normal saline 20 mins prior to surgery and Group C received intravenous saline of $5 \mathrm{~mL}$ as placebo 20 mins prior to surgery. Heart rate and blood pressure (SBP, DBP and MAP) were recorded at baseline after premedication at induction, at intubation and 2, 4, 6, 8 and 10 minutes after intubation. Induction was done with propofol under Bispectral guidance and dose of propofol needed was noted.

\section{RESULTS}

When compared to midazolam and clonidine, there was a significant increase in HR and MAP in control group after laryngoscopy and tracheal intubation and also doses of propofol needed were more. Clonidine was better than midazolam in suppressing the tachycardia associated with laryngoscopy and intubation. Midazolam showed a better response than clonidine in decreasing MBP all throughout the study, but the statistical difference was not significant. However, doses of propofol needed for induction were comparable in both midazolam and clonidine group, but were much less than control group.

\section{CONCLUSION}

Both midazolam and clonidine pre-treatment provided adequate sedation, has dose sparing effect on propofol, partially blunts haemodynamic responses and decreases PONV. In addition, clonidine also demonstrated superiority in reducing postoperative shivering.

\section{KEY WORDS}

Midazolam, Clonidine, Propofol, Haemodynamic Changes and Endotracheal Intubation.

HOW TO CITE THIS ARTICLE: Lall T, Singh D, Dutta V, et al. To compare the efficacy of intravenous midazolam versus clonidine as premedicants on bispectral index-guided propofol induction of anaesthesia in general surgery. J. Evolution Med. Dent. Sci. 2018;7(23):2767-2772, DOI: $10.14260 /$ jemds/2018/625

\section{BACKGROUND}

Surgery and anaesthesia are stressful conditions and are associated with stimulation of neuroendocrinal pathway, producing various haemodynamic effects, which may be harmful to the patient. Methods to decrease these effects include maintaining an adequate depth of anaesthesia to prevent these haemodynamic effects or to give some pharmacological preparation to the patients, which will modify the response of anaesthetic drug.

'Financial or Other Competing Interest': None.

Submission 26-04-2018, Peer Review 20-05-2018,

Acceptance 28-05-2018, Published 04-06-2018.

Corresponding Author:

Dr. Tarun Lall,

\#54/A, Devi Path,

Kanota Bagh,

Jaipur-302004,

Rajasthan, India.

E-mail: tlall258@hotmail.com

DOI: $10.14260 /$ jemds $/ 2018 / 625$

\section{(c) (i) $\odot$}

Use of midazolam as premedicant during induction showed significant reduction in propofol dose, low maintenance requirements of anaesthetics, less airway irritability and blood pressure (BP) increase. Administration of clonidine preoperatively has been shown to potentiate the effects of anaesthetics and decreases the requirement of propofol.[1][2][3][4][5][6][7][8]

However, clinically optimised focusing of drug administration to a specific need of patient with bispectral index (BIS) monitoring results in reduced dosage of anaesthetic agents and faster recovery of consciousness.[6][9] Propofol is an intravenous agent for induction and maintenance as well as for sedation in the intensive care unit (ICU). It has rapid induction, short duration of action and smooth, clear-headed and nausea-free emergence. This excellent profile makes it possible to control the levels of anaesthesia and sedation with ease. However, when used as a sole induction agent it can cause cardiopulmonary depression, especially in the elderly. The degree of hypotension, severity of bradycardia and duration of apnoea are related to the dose 
and speed of injection, which can be minimised or eliminated when propofol is co-induced with midazolam.[10]

\section{Aims and Objectives}

To compare efficacy of intravenous midazolam versus clonidine as premedicants on bispectral index-guided propofol induction of anaesthesia in general surgery using following parameters.

\section{Primary Objectives}

- Haemodynamic changes (SBP, DBP, HR).

\section{Secondary Objectives}

1. To compare the requirement of propofol between these three groups taking BIS as index.

2. To note the complications if any.

\section{Study Design}

It was hospital-based, randomised, double blind, comparative study design.

\section{Sample Size}

The sample size was calculated 43 (rounded off to 45) subjects in each 3 groups at $\alpha$ error 0.05 and power $80 \%$ assuming the differences in heart rate to be 9 per minute and $S D=13$ (as per seed article). So for the study purpose, total 135 cases in which 45 cases of general surgery for Inj. Midazolam and 45 cases for Inj. Clonidine and 45 cases for control group will be taken.

\section{MATERIALS AND METHODS}

After approval from the Institutional Ethical Committee, 135 patients with study eligibility of ASA grade I and II, aged 20-60 years, posted for elective surgery under general anaesthesia were selected and randomly allocated into three groups of 45 patients each by using 'Chit in box' technique. This trial was so planned that neither the doctor nor the participant was aware of the group allocation and the drug received.

\section{Group (A) (n= 45)}

Injection midazolam $50 \mathrm{mcg} / \mathrm{kg}$ diluted to total volume of 5 $\mathrm{mL}$, injected slow IV 20 mins prior to surgery.

\section{Group (B) (n= 45)}

Injection clonidine $1.5 \mathrm{mcg} / \mathrm{kg}$ diluted to total volume of $5 \mathrm{~mL}$, injected slow IV 20 mins prior to surgery.

\section{Group (C)= Control Group $(n=45)$}

Normal saline $5 \mathrm{~mL}$ (Control group) was injected slow IV 20 mins prior to surgery.

Patient with major organ dysfunction (hypertension, cerebrovascular disease, ischaemic heart disease, arrhythmias, shock), on medications (like hypnotics, narcotics analgesics, $\alpha_{2}$ agonists, calcium channel blockers, $\beta$ blockers) and with reactive airway diseases, having known allergy to anaesthetic agents used in study with anticipated difficult intubation, pregnancy/ lactation and in whom intubation was done after more than 1 attempt or more than 20 seconds were excluded from the study.
Pre-anaesthetic check-up was done in all patients as per institutional protocol. Written informed consent was taken for performance of general anaesthesia after complete explanation about the study protocol. 135 patients were randomly allocated into 3 groups of 45 each. Group A received midazolam $50 \mathrm{mcg}$, Group B received clonidine $1.5 \mathrm{mcg}$ and Group C received placebo intravenous as premedication 20 mins prior to induction of general anaesthesia. Anaesthesiologist who was not aware of the study protocol and was not participating in study was the observer.

On arrival in the operation theatre fasting status, written informed consent and PAC was checked. All the routine monitors were attached and the preoperative baseline vitals i.e. heart rate (HR), systolic blood pressure (SBP), diastolic blood pressure (DBP), mean arterial pressure (MAP), SpO2 and ECG were noted. Intravenous line was secured and IV fluid Ringer Lactate started.

\section{Premedication and Induction}

Patients were oxygenated simultaneously and premedicated with Inj. ranitidine- $1 \mathrm{mg} / \mathrm{kg}$, metoclopramide- $0.2 \mathrm{mg} / \mathrm{kg}$, then Inj. tramadol- $2 \mathrm{mg} / \mathrm{kg}$, Inj. Glycopyrrolate- $5 \mathrm{mcg} / \mathrm{kg}$. Followed by infusion of propofol at $30 \mathrm{mg} / \mathrm{kg} / \mathrm{h}$ until BIS stabilised at $48 \pm 2$ and remained stable for that. Once the desired BIS value was reached, propofol infusion was switched off and total dose of propofol was noted. Then patient was given Inj. succinylcholine $2 \mathrm{mg} / \mathrm{kg}$ body weight, ventilated and then intubated with cuffed endotracheal tube under direct laryngoscopy. The value of BIS and haemodynamic parameters were noted at the time of loss of consciousness, at the time of intubation with cuffed ET tube under direct laryngoscopy and thereafter every 2 mins for first 10 mins following intubation.

In all the patients, the ETT cuff was filled with air depending upon the minimal occlusion volume (volume at which no palpable leak will be felt over the trachea) of each patient and initial cuff pressure was noted. Care was taken to ensure that the starting cuff pressure was approximately 25 $\mathrm{cm} \mathrm{H2O}$, measured using a high volume, low-pressure ETT cuff manometer.

\section{Maintenance}

Anaesthesia was maintained with N20/02 (60/40\%) and isoflurane $0.6 \%$. Further neuromuscular block was maintained with intermittent boluses of atracurium (one-quarter of the intubating dose at 15 mins interval).

\section{Extubation}

After surgery, isoflurane was discontinued. The circuit was flushed with 02 to remove residual inhalational agent and residual neuromuscular block was reversed with neostigmine $(0.05 \mathrm{mg} / \mathrm{kg})$ and glycopyrrolate $(0.01 \mathrm{mg} / \mathrm{kg})$. Mechanical ventilation was maintained until swallowing or spontaneous ventilation resumed and then patient was extubated when the following criteria were met: (1) Spontaneous ventilation; (2) Ability to follow verbal commands (Eye opening or hand grip) and (3) Ability to demonstrate purposeful movements. Postoperative complications if any were noted. 


\section{Statistical Analysis}

All the quantitative data were summarised in the form of mean and standard deviation and was analysed using One-Way ANOVA with post hoc Bonferroni test (for intergroup comparison). Qualitative data was expressed as number and percentage and analysed using Chi-square test. A p-value less than 0.05 was taken as statistically significant. All statistical analysis was done using SPSS trial version 20.

\section{RESULTS}

A total 135 patients were induced into the study. There were no statistically significant differences in the demographic parameters such as Age, Sex, Weight, Height, ASA physical status, Mallampati grading and duration of laryngoscopy among the study groups. The patients were in the age group of 20 - 60 yrs. In our study, there was slight male preponderance.

\begin{tabular}{|c|c|c|c|c|}
\hline Particulars & Group A & Group B & Group C & P value \\
\hline $\begin{array}{l}\text { Age(years) } \\
(\text { Mean } \pm \text { SD) }\end{array}$ & $35.4 \pm 11.3$ & $34.3 \pm 11.1$ & $38.9 \pm 11.4$ & $\begin{array}{c}0.141 \\
(\mathrm{NS}) \\
\end{array}$ \\
\hline $\begin{array}{c}\text { Sex } \\
\text { (male:female) }\end{array}$ & $39: 6$ & $38: 7$ & $40: 5$ & $\begin{array}{l}0.825 \\
(\mathrm{NS})\end{array}$ \\
\hline $\begin{array}{l}\text { Weight(kg) } \\
\text { (Mean } \pm \text { SD) }\end{array}$ & $55.50 \pm 7.57$ & $58.30 \pm 7.57$ & $56.60 \pm 7.57$ & $\begin{array}{c}0.157 \\
\text { (NS) }\end{array}$ \\
\hline $\begin{array}{l}\text { Mallampati } \\
\text { grading(I:II) }\end{array}$ & $38: 2$ & $39: 1$ & $38: 2$ & $\begin{array}{l}0.815 \\
\text { (NS) }\end{array}$ \\
\hline ASA(I:II) & $32: 12$ & $28: 17$ & $27: 18$ & $\begin{array}{c}0.407 \\
\text { (NS) }\end{array}$ \\
\hline $\begin{array}{c}\text { Laryngoscopy } \\
\text { time sec } \\
\text { (Mean } \pm \text { SD) }\end{array}$ & $17.17 \pm 1.61$ & $17.12 \pm 1.75$ & $16.87 \pm 1.82$ & $\begin{array}{c}0.710 \\
(\mathrm{NS})\end{array}$ \\
\hline \multicolumn{5}{|c|}{ Table 1. Demographic Parameters } \\
\hline
\end{tabular}

In midazolam group, the mean HR values were lesser than the baseline values at premedication, induction and 2 mins, and thereafter after intubation. Though there was a slight increase after intubation, but the difference was statistically insignificant. In clonidine group the mean HR values were lesser than the baseline values, but there was a slight increase in mean HR post intubation, but then again decreased below the baseline value at 2 mins and thereafter after intubation. In control group, the mean HR values were lesser than the baseline values at premedication, induction and 2 mins, and thereafter after intubation. There was a slight increase after intubation. But the mean HR values decreased after induction and at 2 mins and thereafter after intubation. There was no significant difference between the baseline values of mean heart rates in all the groups. (It was $80.0 \pm 12.6$ for midazolam group, $81.6 \pm 12.4$ for clonidine group and $83.1 \pm 12$ for control group). Clonidine showed a better response at induction and intubation than midazolam and control group with a significant difference statistically. It had better obtundation over increase in mean heart rate after premedication than midazolam and control group.

\begin{tabular}{|c|c|c|c|c|}
\hline Time Point & Midazolam & Clonidine & Control & P value \\
\hline Baseline & $80.0 \pm 12.6$ & $81.6 \pm 12.4$ & $\begin{array}{c}83.1 \pm \\
12\end{array}$ & 0.495 \\
\hline $\begin{array}{c}\text { Pre- } \\
\text { medication }\end{array}$ & $77.1 \pm 11.3$ & $\begin{array}{c}76.5 \pm \\
12.4^{*}\end{array}$ & $78.1 \pm 12^{*}$ & 0.807 \\
\hline Induction & $78.4 \pm 10.8$ & $\begin{array}{c}66.9 \pm \\
11.5^{*}\end{array}$ & $75.1 \pm 11.5$ & $\begin{array}{c}<0.001 \\
1 \text { vs } 2 \text { and } \\
3 \text { vs } 2)\end{array}$ \\
\hline Intubation & $87.5 \pm 9.2^{*}$ & $\begin{array}{c}78.5 \pm \\
12.5^{*}\end{array}$ & $86.1 \pm 11.2^{*}$ & $\begin{array}{c}<0.001 \\
\text { vs } 2 \text { and } \\
2 \text { vs } 3)\end{array}$ \\
\hline \multicolumn{5}{|c|}{ Post Intubation } \\
\hline
\end{tabular}

\begin{tabular}{|c|c|c|c|c|}
\hline 2 mins & $75.4 \pm 10.2^{*}$ & $\begin{array}{c}73.4 \pm \\
12.0^{*}\end{array}$ & $79.1 \pm 10.6^{*}$ & $\begin{array}{c}0.048 \\
(2 \mathrm{vs} 3)\end{array}$ \\
\hline 4 mins & $73.4 \pm 9.1$ & $71.3 \pm 11.2$ & $77.1 \pm 10.6$ & $\begin{array}{c}0.030 \\
(2 \mathrm{vs} 3)\end{array}$ \\
\hline 6 mins & $72.5 \pm 9$ & $70.4 \pm 11.3$ & $76 \pm 11.1$ & $\begin{array}{c}0.041 \\
(2 \mathrm{vs} 3)\end{array}$ \\
\hline 8 mins & $71.7 \pm 8.8$ & $70.2 \pm 12.5$ & $75.0 \pm 11.1$ & 0.107 \\
\hline 10 mins & $73.7 \pm 8.8$ & $72.2 \pm 12.5$ & $76.9 \pm 10.7$ & 0.113 \\
\hline \multicolumn{6}{|c}{ Table 2. Mean Heart Rate at Various Time Intervals } \\
\hline
\end{tabular}

*Significant difference in relation to value at time just previous to it within the group.

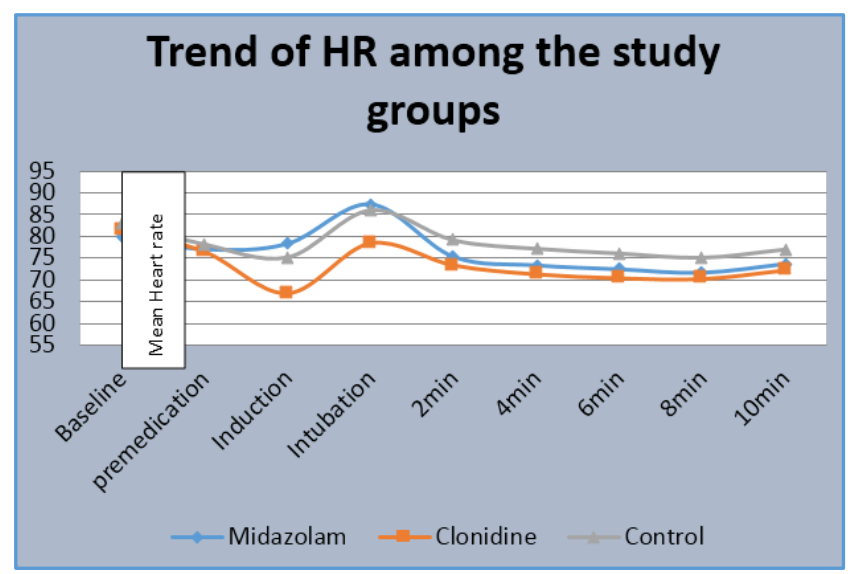

\begin{tabular}{|c|c|c|c|c|}
\hline Time Point & Midazolam & Clonidine & Control & P value \\
\hline Baseline & $95.4 \pm 10.8$ & $94.4 \pm 10.4$ & $95 \pm 8$ & 0.875 \\
\hline $\begin{array}{c}\text { Pre- } \\
\text { medication }\end{array}$ & $88.4 \pm 9.6^{*}$ & $87.1 \pm 9.1^{*}$ & $87.5 \pm 7.2^{*}$ & 0.781 \\
\hline Induction & $79.6 \pm 9.7$ & $73.3 \pm 7.8^{*}$ & $73.7 \pm 6^{*}$ & $\begin{array}{c}<0.001 \\
(1 \text { vs } 2 \\
\text { and } \\
1 \text { vs } 3)\end{array}$ \\
\hline Intubation & $94.1 \pm 10.8^{*}$ & $93 \pm 10.4$ & $93.7 \pm 8$ & 0.875 \\
\hline \multicolumn{5}{|c|}{$\begin{array}{ll} & \text { Post Intubation } \\
\end{array}$} \\
\hline 2 mins & $84.7 \pm 10.2^{*}$ & $88.4 \pm 10.6$ & $91 \pm 8.1$ & $\begin{array}{c}0.010 \\
(1 \text { vs } 3)\end{array}$ \\
\hline 4 mins & $82.7 \pm 9.7$ & $87 \pm 9.9$ & $89.6 \pm 8$ & $\begin{array}{c}0.002 \\
(1 \text { vs } 3)\end{array}$ \\
\hline 6 mins & $84.3 \pm 9.8$ & $88.0 \pm 10.3$ & $90.8 \pm 7.7$ & $\begin{array}{c}0.005 \\
(1 \text { vs } 3) \\
\end{array}$ \\
\hline 8 mins & $83.7 \pm 8.9$ & $88 \pm 9.7$ & $90.6 \pm 7.4$ & $\begin{array}{c}0.001 \\
(1 \text { vs } 3)\end{array}$ \\
\hline 10 mins & $83 \pm 10.2$ & $87.5 \pm 11.2$ & $89.6 \pm 7.9$ & $\begin{array}{c}0.006 \\
(1 \text { vs } 3)\end{array}$ \\
\hline
\end{tabular}

*Significant difference in relation to value at time just previous to it within the group.

In all groups, the mean of MBP was lesser than the baseline value all throughout the study period.

There was no significant difference between the baseline values of mean MAP in the groups. (It was $95.4 \pm 10.8 \mathrm{mmHg}$ for Midazolam group, $94.4 \pm 10.4 \mathrm{mmHg}$ for Clonidine group and $95 \pm 8 \mathrm{mmHg}$ for Control group).

Midazolam showed a better response than clonidine in decreasing MBP all throughout the study, but the statistical difference was not significant. In comparison to control group, midazolam group showed much better response at induction 
and post intubation and statistical difference was significant at induction and after two minutes post intubation.

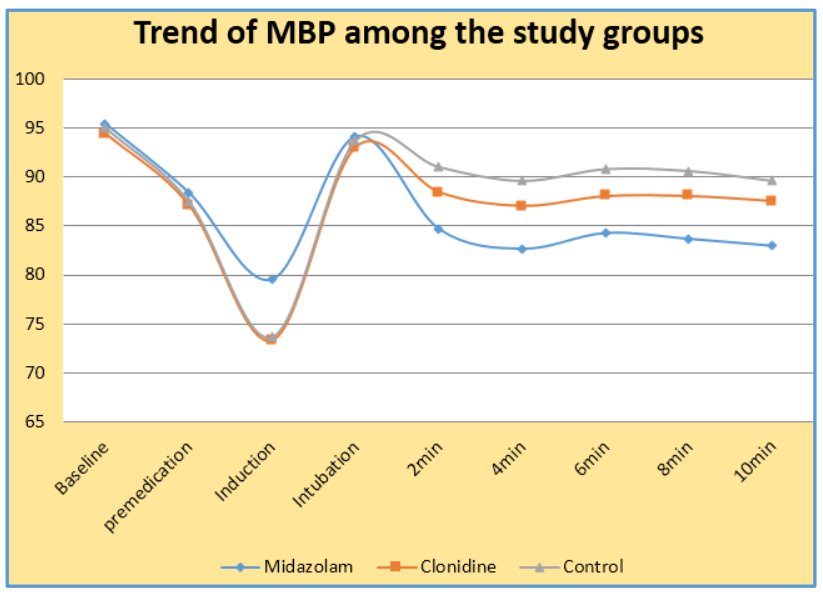

The mean oxygen saturation remained above $98 \%$ in these groups at all the point of study. There was no significant differences in oxygen saturation among these groups. There was no respiratory depression in these groups. There was no drop in oxygen saturation in these groups.

There was no incidence of ECG abnormality, hypotension or bradycardia in all groups, but unsteadiness and nausea were found in $5 \%$ of case in pregabalin group post-op.

\begin{tabular}{|c|c|c|c|c|}
\hline Group & N & Mean & Std. Deviation & Range \\
\hline Midazolam & 45 & 79.1 & 10.09 & $40-130$ \\
\hline Clonidine & 45 & 81.3 & 14.14 & $41-130$ \\
\hline Control & 45 & 109.0 & 18.16 & $70-147$ \\
\hline Table 4. Comparison of Mean Propofol Dose required by \\
(mg/kg) Study Groups
\end{tabular}

One-Way ANOVA- F= 59.448; $\mathrm{P}<0.001$ (S)

\section{Post Hoc Bonferroni Test}

For midazolam vs clonidine: $p$ value $=1.000$ (NS) for midazolam and clonidine vs controls: $p$ value $<0.001$ (S).

On comparing the mean propofol dose required between midazolam and clonidine groups $(79.1 \mathrm{mg}$ for midazolam versus $81.3 \mathrm{mg}$ for clonidine), the difference was not significant. However, on comparing midazolam and clonidine groups with control group (79.1 mg for midazolam versus 81.3 $\mathrm{mg}$ for clonidine versus $109 \mathrm{mg}$ for control) the difference was significant.

\section{Comparison of mean propofol dose required by study groups}

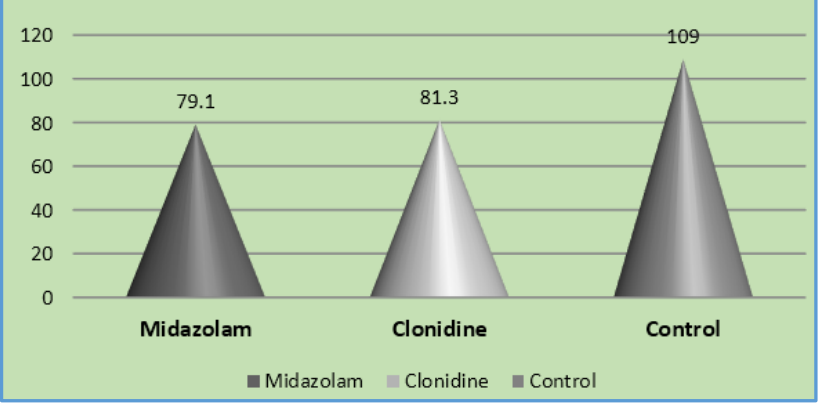

\begin{tabular}{|c|c|c|c|c|}
\hline Time Point & Midazolam & Clonidine & Control & P value \\
\hline Baseline & $87.6 \pm 1.9$ & $87.4 \pm 1.7$ & $87.5 \pm 1.7$ & 0.774 \\
\hline $\begin{array}{c}\text { Pre- } \\
\text { medication }\end{array}$ & $71.9 \pm 3.3^{*}$ & $73 \pm 3.1^{*}$ & $72.5 \pm 3.5^{*}$ & 0.298 \\
\hline Induction & $47.6 \pm 1.1^{*}$ & $47.5 \pm 1.1^{*}$ & $47.7 \pm 1.3^{*}$ & 0.767 \\
\hline Intubation & $55.2 \pm 2.6^{*}$ & $59.9 \pm 2.9^{*}$ & $61.1 \pm 2.6^{*}$ & $\begin{array}{c}<0.001(1 \text { vs } 2 \\
\text { and 1 vs 3) }\end{array}$ \\
\hline $\begin{array}{c}\text { Post } \\
\text { Intubation }\end{array}$ & $46.9 \pm 1.6^{*}$ & $48.1 \pm 1.9^{*}$ & $50.8 \pm 1.7^{*}$ & $\begin{array}{c}<0.001 \text { (1 vs } 2 \\
\text { and vs 3 and } \\
2 \text { vs 3) }\end{array}$ \\
\hline \multicolumn{4}{|c|}{ Table 5. Trend of BIS among the Study Groups } \\
\hline \multicolumn{5}{|c}{} \\
\hline
\end{tabular}

*Significant difference in relation to value at time just previous to it within the group.

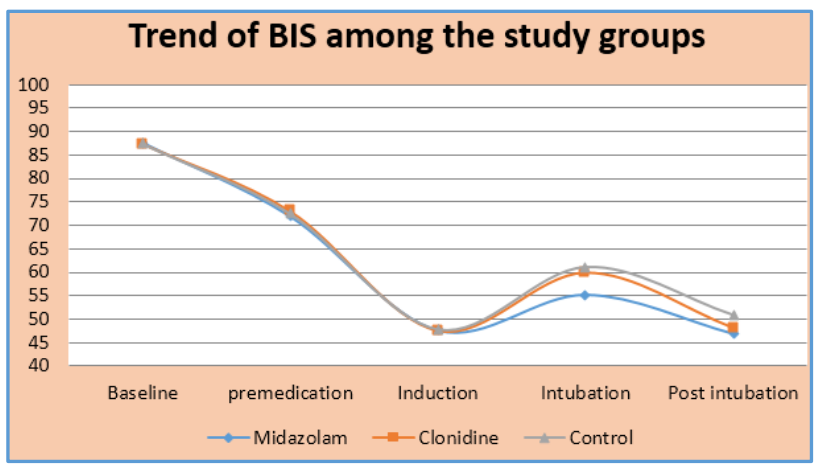

\begin{tabular}{|c|c|c|c|c|}
\hline $\begin{array}{c}\text { Compli- } \\
\text { cation }\end{array}$ & $\begin{array}{c}\text { Mida } \\
\text { zolam }\end{array}$ & Clonidine & Control & P value \\
\hline Shivering & $9(20 \%)$ & $3(6.7 \%)$ & $16(35.6 \%)$ & 0.003 \\
\hline Nausea & $5(11.1 \%)$ & $5(11.1 \%)$ & $13(28.9 \%)$ & 0.035 \\
\hline Pain, No & & & & \\
pain & $2(4.4 \%)$ & $6(13.3 \%)$ & $6(13.3 \%)$ & \\
Mild & $33(73.3 \%)$ & $33(73.3 \%)$ & $26(57.8 \%)$ & 0.307 \\
Moderate & $8(17.8 \%)$ & $6(13.3 \%)$ & $10(22.2 \%)$ & \\
Severe & $2(4.4 \%)$ & $0(0 \%)$ & $3(6.7 \%)$ & \\
\hline
\end{tabular}

Table 6. Frequency of Complication in the Study Groups

Out of a total of 45 patients in midazolam group, 9 had shivering and 5 had nausea in clonidine group, 3 had shivering and 5 had nausea. While in control group, 16 patients had shivering and 13 had nausea and there was bradycardia (HR < 60 ) on two occasions and hypotension (mean $\mathrm{BP}<60 \mathrm{mmHg}$ ) on two occasions in clonidine group and in four occasions in midazolam group.

To conclude, both midazolam and clonidine group showed less shivering and nausea as compared to placebo. However, clonidine group was superior to midazolam in preventing shivering, but the difference was not statistically significant.

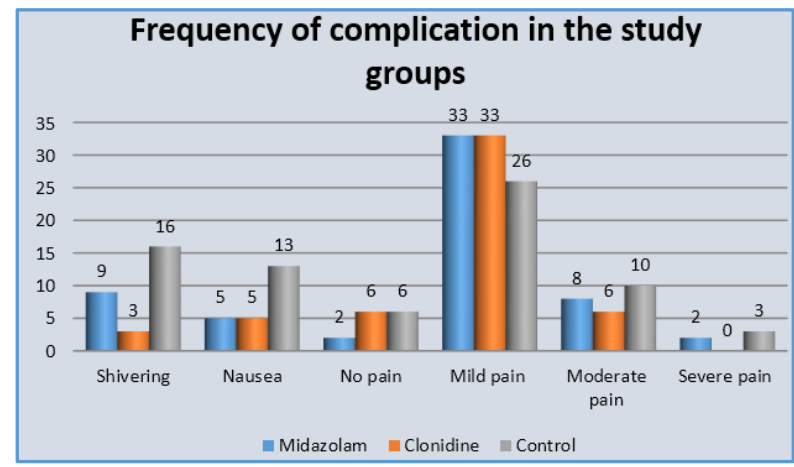




\section{DISCUSSION}

In our study, we found the decrease in dose of propofol needed as induction agent while using midazolam and clonidine as premedicants. We found $27.4 \%$ decrease in propofol dose while using midazolam $.05 \mathrm{mg} / \mathrm{kg}$ IV as premedicant, whereas $25.4 \%$ decrease while using clonidine $1.5 \mu \mathrm{g} / \mathrm{kg}$ IV as premedicant as compared to placebo. The decrease in dose of propofol with the use of midazolam and clonidine was shown by other authors ${ }^{[1][3][4][5][6][7][10][11][12][8][13][14]}$ also, though the difference was variable. This variation in case of clonidine may be due to the use of clonidine ${ }^{[1][4][5] ~ i n ~ h i g h e r ~ d o s e s ~ o r a l l y ~ i n ~}$ dose of $4-5 \mu \mathrm{g} / \mathrm{kg}$, whereas we used clonidine in dose of 1.5 $\mu \mathrm{g} / \mathrm{kg} \mathrm{IV}$.

This study supports that induction doses of propofol required were less with midazolam[1] premedication as compared to clonidine clinically, which could be due to the fact that both propofol and midazolam have been known to have a depressive effect on the CNS via GABA-A receptor-mediated inhibition and share a common receptor or exert effect on the GABA-A receptor.

Target-controlled infusion provides a precise blood concentration of propofol, but due to its unavailability in our setup at the time of study we used the infusion of propofol at the rate of $30 \mathrm{mg} / \mathrm{kg} / \mathrm{h}$ as in study conducted by Arya $\mathrm{S}$ et al.[15]

Clonidine is more effective in blunting the reflex tachycardia associated with laryngoscopy and endotracheal intubation, ${ }^{[16]}$ reduced intraoperative lability of BP, HR as well as decrease in dosage of narcotics ${ }^{[4]}$ and their supplementations. The inhibitory effects of clonidine on central monoaminergic system may be the possible cause for the above finding. Similar findings were seen in the other studies. ${ }^{[3][4][5][6]}$

However, we inferred that neither clonidine nor midazolam premedication completely block the cardiovascular response to laryngoscopy and tracheal intubation due to the mechanical stimuli from the larynx and base of the tongue and their effect is dose dependent.

Though, there is potential anaesthetic dose sparing effect seen with clonidine premedication, but bradycardia and hypotension are also observed with its use. A study has shown bradycardia and hypotension only with $5 \mu \mathrm{g} / \mathrm{kg}$ that is higher than the dose used in our study. The activation of presynaptic alpha- 2 adrenoreceptors in peripheral nervous terminations inhibits norepinephrine exocytosis partially explaining the hypotensive and bradycardia inducing effects of such receptor agonists.[17]

The BIS monitor is a well-established monitor for measuring depth of anaesthesia. Bispectral index value increases significantly after tracheal intubation. Such response can be reduced by premedication with midazolam or clonidine, which is in agreement with the findings of Paris et al.[18]

In this study, the incidence of shivering was least with use of clonidine as premedicant. This has been attributed to the well-known anti-shivering effects of clonidine at three levels: Hypothalamus, locus coeruleus and spinal cord as postulated by Basker et al and Bergendahl et al.[19]

Clonidine also affords an advantage of reduction in PONV, although many workers have reported the antiemetic property of clonidine, the mechanism by which it reduces PONV needs further investigation.[20][21] Our study demonstrated nearly equal efficacy of midazolam and clonidine as premedicants in sparing propofol dose. Midazolam attenuates cardiovascular response to laryngoscopy and intubation nearly as well as clonidine except for HR.

\section{The Limitations of our Study were that-}

1. Unavailability of target-controlled infusion in our setup at the time of study, which could have provided a precise blood concentration of propofol.

2. We did not estimate the level of stress hormones at the time of anaesthesia induction and intubation, which would have given a better idea of changes in stress level after premedication.

\section{CONCLUSION}

To conclude both midazolam and clonidine pre-treatment provided adequate sedation, has dose sparing effect on propofol, partially blunts haemodynamic responses and decreases PONV. In addition, clonidine also demonstrated superiority in reducing postoperative shivering. However, different route of administration, dosing, combinations and time interval between premedication and intubation might affect the efficacy of drugs. Hence, further studies are recommended to find out the optimal dose and route to get the best results.

\section{REFERENCES}

[1] Kodaka M, Okamoto Y, Kakoi H, et al. The effects of premedication on induction doses of propofol and hemodynamic responses during induction. Masui 1997;46(10):1347-53.

[2] Ghignone M, Quintin L, Duke PC, et al. Effects of clonidine on narcotic requirements and hemodynamic response during induction of fentanyl anesthesia and endotracheal intubation. Anesthesiology 1986;64(1):36-42.

[3] Guglielminotti J, Descraques C, Petitmaire S, et al. Effects of premedication on dose requirements for propofol: Comparison of clonidine and hydroxyzine. $\mathrm{Br}$ J Anaesth 1998;80(6):733-6.

[4] Imai Y, Mammoto T, Murakami K, et al. The effects of preanesthetic oral clonidine on total requirement of propofol for general anesthesia. J Clin Anesth 1998;10(8):660-5.

[5] Goyagi T, Tanaka M, Nishikawa T. Oral clonidine premedication reduces induction dose and prolongs awakening time from propofol-nitrous oxide anesthesia. Can J Anaesth 1999;46(9):894-6.

[6] Friedberg BL, Sigl JC. Clonidine premedication decreases propofol consumption during bispectral index (BIS) monitored propofol-ketamine technique for office-based surgery. Dermatol Surg 2000;26(9):84852.

[7] Fehr SB, Zalunardo MP, Seifert B, et al. Clonidine decreases propofol requirements during anaesthesia: effect on bispectral index. Br J Anaesth 2001;86(5):62732.

[8] Steeds C, Orme R. Premedication. Anaesth Intensive Care Med 2006;7(11):393-6.

[9] Donald RS, Stevan LS. Miller's Anesthesia. In: Miller RD, edr. $6^{\text {th }}$ edn. Philadelphia: Elsevier Churchill Livingstone 2005: p. 1250-7. 
[10] Kataria R, Singhal A, Prakash S, et al. A comparative study of efficacy of propofol auto-co-induction versus midazolam propofol co-induction using the priming principle. Indian J Anaesth 2010;54(6):558-61.

[11] Wilder-Smith OH, Ravussin PA, Decosterd LA, et al. Midazolam premedication reduces propofol dose requirements for multiple anesthetic endpoints. Can J Anaesth 2001;48(5):439-45.

[12] Zeng WA, Wang J, Lin WQ, et al. Effects of midazolam premedication on induction doses of propofol and hemodynamic changes during tumor patient induction. Ai Zheng 2002;21(6):678-80.

[13] Bhaskar P, Malik A, Kapoor R, et al. Effect of midazolam premedication on the dose of propofol for laryngeal mask airway insertion in children. J Anaesthesiol Clin Pharmacol 2010;26(4):503-6.

[14] Cressey DM, Claydon P, Bhaskaran NC, et al. Effect of midazolam pretreatment on induction dose requirements of propofol in combination with fentanyl in younger and older adults. Anaesthesia 2001;56(2):108-13.

[15] Arya S, Asthana V, Sharma JP. Clinical vs. bispectral index-guided propofol induction of anesthesia: a comparative study. Saudi J Anaesth 2013;7(1):75-9.
[16] Marashi SM, Ghafari MH, Saliminia A. Attenuation of hemodynamic responses following laryngoscopy and tracheal intubation - comparative assessment of clonidine and gabapentin premedication. Middle East J Anesthesiol 2009;20(2):233-7.

[17] Ezri T, Szmuk P, Shklar B, et al. Oral clonidine premedication does not prolong analgesia after herniorrhaphy under subarachnoid anesthesia. J Clin Anesth 1998;10(6):474-81.

[18] Paris A, Kaufmann M, Tonner PH, et al. Effects of clonidine and midazolam premedication on bispectral index and recovery after elective surgery. Eur J Anaesthesiol 2009;26(7):603-10.

[19] Bergendahl HT, Lönnqvist PA, Eksborg S, et al. Clonidine vs. midazolam as premedication in children undergoing adeno-tonsillectomy: a prospective, randomized, controlled clinical trial. Acta Anaesthesiol Scand 2004;48(10):1292-300.

[20] Sümpelmann R, Brauer A, Krohn S, et al. Effects of intravenous clonidine on recovery and postanaesthetic analgesic requirements. Schmerz 1994;8(1):51-6.

[21] Zhao H, Ishiyama T, Oguchi T, et al. Effects of clonidine and midazolam on postoperative shivering, nausea and vomiting. Masui 2005;54(11):1253-7. 